DOI: $10.19275 /$ RSEP078

Received: 05.01 .2020

Accepted: 07.03.2020

\title{
INVESTMENT-CASH FLOW SENSITIVITY AND FINANCING CONSTRAINTS: A STUDY OF PAKISTANI BUSINESS GROUP FIRMS
}

\author{
Yasir Mehmood \\ MS-Banking and Finance, department of management sciences, COMSATS University \\ Islamabad-Abbottabad Campus, Pakistan. \\ yasirpk30@gmail.com \\ Syed Amjad Farid Hasnu \\ Professor, department of management sciences, COMSATS University Islamabad- \\ Abbottabad Campus, Pakistan. \\ hasnu@cuiatd.edu.pk
}

\begin{abstract}
A large discrepancy exists on the use of the investment-cash flow sensitivity as a measure of financing constraints of firms. We examine this discrepancy by considering business group affiliated firms in Pakistan. The study includes 58 group affiliated firms and 32 non-group affiliated firms listed on the Karachi Stock Exchange during 20062010. Results of OLS and 2SLS shows a positive investment-cash flow sensitivity for business group affiliated firms and negative investment cash flow sensitivity for nongroup affiliated firms. Additional tests accordingly express that investment-cash flow sensitivity of Pakistani group affiliated firms is significantly lower to non-group affiliated firms.
\end{abstract}

Keywords: Investment-Cash flow, 2SLS, Financing constraints, Pakistani Business group Firms

JEL Classification: M13, M21.

Citation: Mehmood, Y. \& Hasnu, S.A.F. (2020). Investment-Cash Flow Sensitivity and Financing Constraints: A Study of Pakistani Business Group Firms, Review of Socio-Economic Perspectives, Vol 5(1), pp. 99-128, DOI: 10.19275/RSEP078. 


\section{Introduction}

\subsection{Background of the study}

Since many years it is the bone of contention among financial scholars that in what relation the investment, financial variables and cash flows are connected to each other. This delicate issue has faced many arguments but still the bottle neck lies as it is According to the Carpenter and Guariglia (2008) as well as Hovakimians (2009), their research generated the results that the impact of cash flow over firm's financial investment especially in the capital markets was not very satisfactory. Compared to the study of Modigliani \& Miller's (1958) according to which they assumed that due the present financial market condition which are facing the existing inadequacy, it's not only important for the firm to keep an eye on its investment possibilities but also important to check that whether the firm has its own intrinsic finances so that they can make appropriate investments. This argument was buck up by many other scholars presenting many articles and papers favouring the positivity and strength of the relationship among the spending of investments and cash flow. According to another study by Fazzari, Hubbard \& Petersen (1988) says that whether the organization faces hindrances regarding their finances or not there is always difference in the assumed investments and the actual investments of the organization. And the company facing financial hurdles does not mean that they are going to affect their internal asset accumulation but in fact they will attack the proper distribution of resources and efficiency of distributing those resources.

From quite a long time the researchers are continuously working on the issue of considering the investment as an embraced or reliant towards the financial pragmatism as well as the link between cash coming in and out and how much the cash is being used for the firm's expansion. The tension between them has generated a new look as displaying the finance idols. To judge the taste of what the firm has cooked(production) and its ingredients used(investment) one should figure out those minor detail which change the colour of ingredients used to cook means affect the essence of dear investment.

Financial constraints have been one of the serious affairs in the business world. This issue comes up when a company must go for financing being opted for either internal financing or external financing. Often internal financing is preferred over external financing. Experts propose that for this, most part depends upon the structure and nature of the business and the economic conditions of the country. Financing constraints can explain why firms don't take abilities of lucrative funding. The results of financing constraints on organization's investment and financing behaviours have been exciting for economists and policy makers for a very long time. The occurrence of financing constraints in general means a state where a windfall increases in cash flow-a variation which tells us that additional data regarding incoming gains and opportunities to put in money has no affect or cannot be linked with money spend for expansion (Bond and Van Reenen, 2007). 


\subsection{Introduction}

Financing constraints depict that how the firms can properly allocate resources in order to get maximum output by making investment in profitable projects to enlarge business. Cash flow is the salient factor to determine the investment opportunities. Along with cash flow sensitivity firm productivity can also be taken as a positive tool to control investment opportunities. Moreover, evidence is provided that elaborates the own assessment and separate the effects of financing constraints from firm-specific effects in another more direct test. Several reasons are provided with justifications for the firms being constrained or unconstrained, the factors that lead to a firm being constrained or unconstrained, and the pros and cons of firms being constrained or unconstrained.

Investment of a firm is well related to its cash flows. It says that quoted organisations are much more likely to be sensitive to cash flow as compared to the unquoted firms. But this doesn't not seem to be happen true since many of the researches have proved that it's been faced by many unquoted firms as well. Danger is more when hindrances outside firm affecting it are more than hindrances inside. Several studies have shown that financing constraints are more appearing in firms of developing financial market countries like Asia.

When the financial market is not perfect and external finance is more costly as compared to within the firm, firm's expansion faces hindrance in that situation become more money spend to handle outside issue mean less money inside the firm to expand. Due to which a variable such as cash flow or liquidity is considered important to Investment decision as a proxy for internal financing. The last two decades indicate the story of a concentrated debate appeared showing that whether financing constraints effect the decision of investment by the firms or not. Some firms obtain external funds so that their investment expenses can be covered. Firms face the problem of under investment because of lack of information problems in financial markets. Investment cash flow sensitivity is related to two things that are under investments and overinvestment. External capital and cash flows are positively correlated to each other (Hovakimian 2009)

Fazzariet al (1988) pioneer researcher generated result that the firm is more dependent on the assets inside the firm because the firm will need money to invest from within the organization means that cash flow inside is more touchy then the external factors but on the other side of the when the firms can easily use the external funds then from inside then the risk decreases from inside to outside.

Sai Ding et al (2010) uses panel data of over 116000 firms from different sectors, registered on Chinese Stock exchange, for the time period 2000-2007. They concluded that those organizations labelled through excessive working capital indicates excessive sensitivities of funding in working capital to cash glide and low sensitivities of investment in fixed capital to cash drift. David and Valeriy (2010) found that the marginal price of investment is higher for constrained firms; nevertheless, high cash holdings are linked with greater ranks of investment for each constrained and unconstrained organisation. 
Toni M. Whited (2006) while in his study of US firms have found that the real investment decisions are being prejudiced by the external financial constraints. Guariglia, A. (2005) studied the panel on 24,184 UK firms over a period of 1993-2003 studies the relation of investment and cash flow relation including all the hindrances involved, which resulted that when there's broaden in the cash flow it impacts the investment in the equal method displaying an expand in investment equal to cash flow. Another study by Zhabgkai Huan (2002) shows that the affiliation among cash flow sensitivity, investment, and financial constraints is curvilinear.

\subsection{Business Groups}

Business groups are known for establishing informal business web throughout the map .They were widely known and considered important for their social networks, links, their vertical and horizontal hierarchy and business dealings. These business groups are distributed wide across the globe from Asia to Europe as well as South America, "keiretsu" and "chaebol" from Japan and Korea are the highlighted one. All of them have gained all lot of fame among different economies.

Guillen (2001) after his extensive study on the business groups concluded that business groups help the countries to develop and the top most business groups have increases countries GDP to the large extent .Taiwan is at the top most having GDP greater than a hundred percent whereas countries like South Korea, India, México, Spain and Indonesia have 40,38,36,35 and 34 percent respectively.

In contrast to the isolated firms, business groups gained much more importance as they minimize the danger of financial defects as well as rules and regulation of the state not matching the firm. Business groups when united they manage to eliminate financial gaps among all the member companies. Distribute the assets of all belonging to each so that States orders can be coped and decrease the risk of financial hurdles. And if the problem occurs the distribution of danger is lower among each then standing alone. In fact, of having many pros it has some cones that having too many shareholders is a problem and when the investment is made at the roots of the companies many managers get involved.

\subsection{Business groups in Pakistan}

The business groups in Pakistan referred to as 'families' where the corporate is run by the family members, are growing. The title of shareholders is leading among the family members. In these business groups one or more family members hold more than one designation. This raises the issue of financing constraints in an economy of less developed financial market (Ghani and Ashraf, 2004).

Business communities of Pakistan and India are almost same forcing them to make business groups. The study on Pakistan business groups' starts from 1974 which calculated the output of 43 business families who were playing the essential part is Pakistan development since 1964 to 1968 and Pakistan's economy builders. Large ratios of these groups who are part of KSC are related to famous business families and some of them have access to the personal property of the shareholders (Zaidi 2006).

Pakistani business groups are the outcome of family business who got permission to legally operated there business independently. These businesses are headed by the families linked by blood and practice the same religious background. Top positions are 
handled by the family which started the business and other junior posts are handled by the distant family members. (Waqar et al, 2010). Ghani et al. (2002) studies business groups and their influence on corporate governance for the period of 1998-2002. Fahad et al (2011) studied the effect of group and family ownership performance; Muhammad Azam and Anum Shah (2011) have studied both internal external financial constraints, and choice for investment.

\section{Literature Review}

\subsection{Financial Constraints}

There are numerous definitions of financial constraints. Kaplan and Zingales (1995) defines financial constraint as: "A firm is considered to be financially constrained if the cost of availability of external funds averts the organization from making an investment it would have chosen to make had internal funds been available". Furthermore, Kaplan and Zingales (1997) gives this definition; "A firm is viewed extra financially constrained because the resort between cost of its internal and outside funds increases". Almeida et al. (2003) also defines fiscal constraints as if an organization has unrestricted access to outside capital, the firm is financially unconstrained and there is no must preserve towards future investment desires and corporate liquidity turns into beside the point. Consistent with Korajczyk and Levy (2003) financially constrained businesses are defined as "firms that should not have enough money to undertake funding opportunities and that face extreme agency expenses when gaining access to economic markets." an additional definition given via Lamont, Polk and Saá-Requejo (2001) describe financial constraints as "frictions that preclude the firm from funding all preferred investments." These financial constraints could arise as a result of "credit constraints or lack of ability to borrow, inability to drawback equity, dependence on bank loans or illiquid assets."

The crux of the matter is that fluctuations in finances do act as a friction. Many examples can be given e.g. problems faced by the companies in getting loan etc. Funds within and outside the organization unless not balanced properly can cause problems because unless and until the organization will not get self-sufficient, they cannot go for investment. Many scholars including Fazzari et al (1988) discussed the same fact and shared their point of view regarding the sensitivity between the investments and cash flows of the organization. They argued that the organization will only go for issuing of debts and share when they will have their own tummy full. So, the strong bonding between investment and cash flow cannot be ignored in fact it should be considered as a serious matter and should be handled with care.

From huge literature hub it has been generated that investment and cash flow do change the financial hindrances of the firm. After the analyses done by Fazzari et al $(1988,2000)$ specified that businesses which undergoes investment decision while the firm faces financial hindrances then it also faces problems of funds availability internally.

A high-quality literature has been accomplished on this hassle to estimate the influence of financial constraints on the investment approach of the firms (Fazzari, Hubbard and Petersen (1988).

Size, capital structure and dividend payouts are the factors that determines that whether financial constraints are sensitive to the flow of internal funds. Firms are said to be highly financially constrained if they are highly sensitive to the cash flows. Studies have 
also exposed the consequences of financial factors on investment decisions by the firms. Some researchers have adopted traditional units of company investment to confirm the firm's investment decisions. In market imperfections, firm investments are sensitive to the internal cash flows.

Initial researches highlighting the names like Fazzari, Hubbard and Petersen who presented that sensitive affiliation between investment and cash flow are the most important statistic of financial variations in the organization .But it faced argument by Kaplan and Zingalas (1997) that this is not the only fact that id responsible for the financial problems occurring in the organization there can be many more.

Cleary (1999) selected some important internal variables effecting internal funds of the organization like liquidity measurement ratio and the coverage ratio, to examine whether the firm is financially strong or not and in 2004 resulted that with respect to investment the following internal hindrances can be focused i-e investment depends on internal funds more funds more investment and the other important hindrance is capital market imperfection. Cleary et al (2007) and DeMarzo and Fishman (2000) after their extensive research have found that the organization going for a specific project only focus on the consequences related to it e.g. how much money is required for the project .Although they give special attention to the unsatisfying funds within the organization and funds to be borrowed externally but it don't affect the organizations projects unless and until they are at high levels.

To study the effects of financing constraints, different tests are conducted which mainly consider market value of the firm to avail investment benefits. Among all most significant and dependable tests are established on investment-cash flow considerations, (Fazzari et al. 1988). In which they have found that it is not the financial structure but the internal net worth of a firm that helps in taking an investment decision. But on the contrary several studies have pointed out drawbacks with the average assessments for the presence of financing constraints on investment-cash flow sensitivities. (Cleary 1999, Kaplan and Zingales 1997, Moyen 2004, Gomes 2001, Alti 2003).

Kaplan and Zingales (1997, 2000), disputed on this test based on theoretical grounds which explains the difference in opinion regarding financial situations between the econometricians and the financial managers of the firms. The strategy adopted by Olley and Pakes (1996) be contingent on the fact that investment stands over the role of efficiency and capital. In this approach financial variable, i.e. cash flow is not considered which is very important.

It is clear and understood after a long journey of investigation and studies that researcher that for larger firms more investment is required and for small firms' small investment is required. (Kadapakkam Rajan Palani et.al, (1998) many other firms some time not only use the internal funds for expansion by sometimes to retain the existing financial position of the firm (Zhangkai Huang (2002).

The company while paying the dividends must concentrate that their decision of paying the dividends may affect their investment (Zhangkai Huang. Z (2002). The relationship between the investments and paying dividend is negative and is of considerable importance (Kadapakkam Rajan Palaniet.al, (1998). 
The above presentation is most favoured by dividing the firm into constrained and less constrained companies'. The companies having low relationship among dividend and income is more likely to be constrained, from this it is suggested that cash flow relation is important for both constrained and non-constrained firms in taking important financial decisions (Allayannis and Mozumdar 2004), (Cleary 1999). Return to capital is significantly greater for firms which believe that financing is a major issue for their business, while the returns are not literally different from zero for the other firms, Cull et al. (2007). This is how the category of constrained and unconstrained firms can also be identified. If the credit is main problem for the entrepreneur, then the firm is constrained and if not, then the firm is unconstrained. The battle of thoughts among cash flow and investment relationship is still open and it is stated that the firm constraints are not only dependent on firms spending in the market but also the firm's capacity to invest i.e. how much investment a firm can put in to the market to cater the opportunities available to invest.

\subsection{Cash flow and investment relationship in Business groups}

Recent studies have shown that business groups are more efficient in developing countries as in comparison with developed countries. Khanna and Palepu (1997, 2000) argue that business groups in constructing nations can impersonator invaluable functions of various market mechanism which are presented only in developed economies. In special conditions where the usage of a specific market mechanism is either constrained or no longer well developed, the structure of the business group can enhance worth by offering member firms with an unconventional way to overcome the missing functions of this mechanism. For example, when the external capital market shouldn't be healthful developed, the operation of an internal capital market within business groups can permit firms to avoid the external capital market, in so doing decreasing informational asymmetry problems between managers and external investors (Myers and Majluf, 1984).

\subsubsection{Business groups}

Business groups in some countries are the most mature and insistent form of organization. They exist in a variety of types, ranging from hierarchical groups with a pyramidal structure to associative groups pursuing their common interest through a more informal system of coordinated decision making. Business groups play a major role in lots of developed and establishing countries. A business group allows firms to reduce their costs, rise above market imperfections and increase their performance (Williamson 1975, Khanna and Pelepu 2000). Business groups have some negative aspects as well (Scharfstein and Stein 2000). Firms associated with business groups are less sensitive to cash flow than those of unaffiliated firms (Perotti and Gelfer 2001). Formation of business groups is associated with axes of social combination such as ethnicity, kinship, region political party and religion, (Granovettor, 1994). This idea was developed by Thompson (1971), identifying this issue with 'moral economy'. Continuing with this business groups are developed based on interpersonal trust (Leff, 1978).Scholars from all over the world have signal the business groups as the market which is expanding day by day and the comparison is made with respect to it with the performance of the firm, business development etc by its relationship with the cash flow is not been noticed at the eye-catching levels. (Khanna and Rivkin 2001, Singh and Gaur 2009) 
All over the globe the business groups follow the same business strategies headed by the same board of directors. Claessens et al (2006). It has been studied that the business groups follow the same strategies and is was figured out the 8 out of 9 countries lying in Asian zone had 15 top business groups having their paws on $20 \%$ of the assets of the corporate. And in Europe 13 out of 10 had greater the $45 \%$ asset control headed by the same business groups Faccio and Lang (2002).

Leff (1978) considered developing economies while studying these institutional factors where business groups happen to exist, he found less efficient capital market and there is absence of market information for risk and uncertainty. These indicators increase transaction cost and the purpose is not achieved efficiently. Lack of these institutional factors causes information asymmetry increasing transaction cost called agency cost, (Jensen and Meckling, 1976).

The performance of business groups varies with different economies. Perotti and Gelfer (1999), conducted a research on business groups in Russia. Keister (1998), studied the performance of business groups in china. Similar research was carried out by Khanna and Rivkin (1999) in the growing economies of Asia, South Africa and Latin America. The outcomes of these researches were that the performance of business groups was seen positive in countries of emerging and transition economies.

Business groups are somehow preferred over non-grouped businesses because of one or the other reason. Primarily business groups are thought to take better investment decisions as the executives and financial managers are family member and are well alert of firm's internal issues, and thus can plan better decisions for long term investments. Secondly the principle agent problems are reduced in business groups because of family management and the agency cost is reduced eventually in the favor of the firm, (Jensen and Meckling, 1976), (Tarziján, 1999).

In business groups the number of major stockholders is insiders i.e. the family members and outsiders are minority. Due to this huge difference in number the minority shareholders can be exploited, Shliefer and Vishny (1997) and Villalonga and Amit (2006).

Business groups can also be encouraged to compete with the market failure. It is the general view that group firms are long lasting in nature and enjoys a goodwill and reputation. Another reason in support of business group is that the leaning firm can finance other firms in case of any failure as there is a chain of firms in the pyramid, (Villalonga and Amit 2006; Wang, 2006; Sraer and Thesmar, 2007; and Maury, 2005).

One very interesting investigation is by Anderson and Reeb (2003) in which he demonstrated that business group firms perform, if not more, at least equivalent to other firms not affiliated to any group. The profits of the firm are even greater when the CEO's of the firm are the family members because the family members are being attached to the firm work more efficiently and with serious dedication.

Johnson et al (2000) found that there is a hierarchy followed throughout the business groups that is they have one CEO heading by the board of directors and rest of the groups. Hierarchal pyramid is made functional following the SOP's at every stage of the pyramid. And this is made by credential transmission as well as related to submission of prices creating problem, co investment, and asset. Following a pyramid increases the 
positive repute of the business groups in the market with respect to family business and it's always better to hire a manager who is not a relative because it has been found the manager from the family has not shown any good results.

According to some studies a noteworthy part of a firm's value belongs to the individual who has control rather than ownership of the firm, Alexander Dyck and Luigi Zingales (2002).If the control rights are greater than the cash flow rights then the funds are diverted and value of the firm decreases, La Porta et al. (2002) and Claessens et al. (2003). The principle of cash flow sensitivity is applied here that affects the investment opportunities. In business groups the control and ownership are within the pyramidal structure that decides the value of the firm. But again, it has some drawbacks regarding flow and direction of funds. The fundamental earnings are not compared with the actual earning but changes in the fundamental earnings are observed in a time period. By comparing these changes, the performance of the pyramidal structure is measured, (Mullainathan et al (2000)

\subsubsection{Business Groups in Pakistan}

Business groups have expanded itself in emerging markets, but they cannot be properly interrogated. They play a vital role in different emerging markets. The most pleasing advantage of working with the business firm is that they reduce the risk of income flow of the member firm and help in smooth and steady flow of money from one firm to another member firm.

After the partition between Pakistan and India in 1947, some of the business families, who were already running their businesses in India, have been migrated to Pakistan to begin their business in Pakistan. This is one of the reasons that Pakistani and Indian business communities have many similarities, and like Indians, Pakistani business communities have formed many business groups.

Pakistani business groups are the outcome of family business who got permission to legally operated there business independently. These businesses are headed by the families linked by blood and practice the same religious background. Top positions are handled by the family which started the business and other junior posts are handled by the distant family members.

As the business groups are headed by single authority so all the rules are followed by the Asian businesses following the hierarchy. As far as Pakistan's businesses it is being headed by most of the family business which are imputing the true essence of hierarchal business by their cultural ingredients (Ghani and Ashraf, 2004).

There are few families in Pakistan which are playing the most vital role towards Pakistan's economy (Zaidi 2006). All those companies which are registered with Karachi stock exchange approximating $80 \%$ enlist belongs to the same business families. But few have the keys to personal assets. These business groups are tackling with the changes occurring across the globe reflecting the business environment as well as their families effectively and efficiently. (Afghan 2007)

It was analysed by Dr. Mahboob in 1968 that most of the wealth lies among the 22 richest families having $66 \%$ control over industries of Pakistan and $87 \%$ share of the insurance and business pie chart. He also reported that these businesses only invested 
more in those businesses in which they can inculcate their polished skills at max. In late 1960's Pakistan was one of the emerging business among the countries under development. As Omer said in the Ayub Khan's era the 22 families created many success stories and they had a remarkable expansion and captured almost all the market. In 1971, when the war ended between Pakistan and India, Z.A became the owner of the state. He forced the prominent 22 families to let their hold over 10 shipping ,13 banks, 12 insurance companies, and 2 petroleum companies for the national people to get jobs and to break the jagirdarri of the famous families leaving behind the textile industry in their hands.(Hussain, Dilawar, daily Dawn, December 9, 2007).During the regime of Nawaz Sharif, who showed liberal and friendly attitude towards these famous 22 families by returning back some units which were nationalized by Z.A in 1980s, at that time some new business families were caught by the eyes as the existing ones expanded their wings more and more in cement and automobiles as well .In the presidential ship of Musharaf same continued.

In 1964-1968 there is not as such differences found between the family business and others with respect to profits, size, control and other things in Pakistan. This was concluded after examining the 43 business companies more than half had directly link with the business families and others were private firms acting in Pakistan. Nishat group, Hashoo group, House of Habib, The Saigols, Cresent group, Saif group, Dewan group etc. are some of the well knower business groups running currently their business in Pakistan.

\subsubsection{Relationship with business group affiliated firms of investment /cash flow.}

From different point of views, it has been figured out that most of the countries show highly sensitive relationship between investment and cash flow like Japan while on the other hand Korean companies don't show such relationship or very low if existed only in group affiliated companies. Showing that financial problems are more in unaffiliated groups in the case of Investments. While other researches show that there is a high relationship between investment and cash flow even in unaffiliated business and some countries show that even member firms don't favor any relationship between cash utilized for expansion and cash coming in and out the firm. These differences occurred from country to country. (Deloof (1998) and Perotti and Gelfer (2001)

Japanese companies are more relaxed being affiliated with groups showing more investments with respect to non-affiliated businesses because they show strong financial relationship with banks having reduced stress of liquidation. As far as non-affiliated firm the risk of investment decision making is more. (Hoshi et al. (1991)

There are different findings that investment and cash flow relation with financial hindrances do affect affiliated business groups as well as non-business affiliated groups. Mainly due to difference of economies, geographical location of the countries and investment trends by the firms. In the light of above discussion, it has been cleared that the studies conducted by different researchers on business groups around the globe show ambiguous link between financial hindrances faced by the firm with relation to investment and cash flow. 


\section{Methodology}

3.1 Q model

Most of the researchers in their study have used different investment models to measure the investment-cash flow sensitivity of a firm. Most commonly used models from researchers in previous studies are Q model of investment and Euler Equation model of investment. Both the models have their own advantages and disadvantages. Among these two models Q model has been widely used by the researcher (Aggarwal and Zong, 2006; Shen and Wang, 2005). In this study we have used only Q model because the Q model has the abilities that it makes use of know-how from capital market hence enabling direct of expected worth of future profitability. The result of the $\mathrm{Q}$ model is more enriching as compared to Euler equation and other investment models. Q model reveals that the investment of a firm is determined by means of anticipations of future profit opportunity, gauged through the constituent of the market value of assets to its replacement value (Agca and Mozumdar, 2008) and Regie et al. (2011).

In order to comprise the accessibility of internal funds as supplementary factor of investment, we have used the same adjusted Q model of Regie et al. (2011) which is written as follows:

$$
\left(\frac{I}{K}\right)_{i t=\beta_{0}+\beta_{1} Q_{i t}+\beta_{2}}\left(\frac{C F}{K}\right)_{i t+\sum} i t
$$

Where,I represent Fixed Asser Investment (FAI) of the firms K is used for Capital Stock of the firm (beginning) $\mathrm{Q}$ denotes ratio of the market value of capital of a firm to its replacement value. $\mathrm{CF}$ is for cash flow of the firm $\mathrm{i}$ and $\mathrm{t}$ are for firm and time period $\sum$ denotes error term. In most of the previous studies, researchers distributed the full sample of the firm across different sectors in order to examine whether, coefficient of cash flow is diverse across the group of the businesses. For this purpose, they have first anticipated the model for entire sample of the firm and then use dummy variable interaction with the cash flow variable of the firm, representing the same characteristics of the firm. Throughout our study we have used this direct approach which has been used by the previous researchers.

The regression description we practise to investigate the precise outcome of business group distinctive is as follows:

$$
\left(\frac{I}{K}\right)_{i t=\beta_{0}+\beta_{1} Q_{i t}+\beta_{2}}\left(\frac{C F}{K}\right)_{i t+\beta_{3}}\left(\frac{C F}{K}\right)_{i t * \text { Group }+\beta 4 \text { Group }+\delta X^{i t}+\sum}
$$

it

In equation (2), we have used some control variable like age, industry, size of the firms. These control variables are represented by $\mathrm{X}_{\mathrm{it}}$. 


\subsection{Data Analysis}

The data used in this study is analyzed by using two different methods which are;

a) OLS Method

The models used in this study are first assessed by using the ordinary least squares (OLS) technique (also called the method of least squares). OLS is used to measure the true relationship between dependent and independent variables. Monica Marina and Greg Niehaus (2011) runs both OLS and 2SLS techniques for their research studies in order to examine the determination of cash holdings and hedging, and their relationship with cash flow. Their results confirm the firms having a positive sensitivity of cash holding and cash flows are more likely to be financially constrained.

\section{b) 2SLS Method}

As we desired to safeguard our outcomes from OLS method from any estimate biasness, we have used the generalized instrumental variables estimation procedure. In order to remove estimation biasness from our results and to deal with the problem of heteroskedasticity and autocorrelation in our econometric model, we have used 2SLS method. For this purpose, we used lagged standards of existing period repressors as instruments. According to Verbeek (2004) the 2SLS estimation method is a distinctive case of the Generalized Method of Moments (GMM) method. The 2SLS technique has been widely used in previous research studies. While reexamining the investment-cash flow sensitivity as measure of financing constraints, Regie et al (2011) in his research has used 2SLS method for both business group affiliated and non-business group firms of India, to ensure that their findings from OLS method are free from any biasness. Anais Hamelin (2012) uses both OLS and 2SLS methods in order to measure the control of family ownership on small business growth in France and found that family ownership have a negative control on small business economic growth he also found that this negative relationship is not due to limit financing capacity by the family ownership. Abdullah et al. (2011) used 2SLS method in order to measure the effect of group and family owner ship on firm performance in Pakistan.

3.3 Variables construction

Dependent variable

- $\quad \mathrm{I} / \mathrm{K}=$ Investment over capital ratio of the firm.

Independent Variables

- $\mathrm{CF} / \mathrm{K}=$ Cash flow over capital ratio of the firm

- $\mathrm{Q}=$ (Market value of equity + book value of total debts/book value of total assets)

Control variables

- Firm Specific-Total Sale of the firm, Total debt of the firm, Total assets of the firms, size and age of the firm

- Ownership structure of a firm- Percentage of shares owned by Corporations, Financial Institutions and directors and family members of the firm.

3.4 Research Hypotheses:

H1: There is a positive relationship between Cash-Flow and Investment.

H2: There is a positive relationship between $Q$ and Investment.

H3: There is a negative relationship between Cash-Flow and individual firms. 
H4: There is a positive relationship between Cash-Flow and Business groups affiliated firms.

H5: There is a negative relationship between Investment and Individuals firms.

H6: There is a positive relationship between Business groups affiliated firms and investment.

3.5 Sample Selection and Data Sources

The initial data for this study is obtained primarily from the publicly available database maintained by the firms and Karachi Stock Exchange (KSE). The data set consists of group and non-group affiliated firms listed on KSE. Sample of the study consists of 90 firms that are traded in Karachi Stock Exchange (KSE) from year 2006 to 2010 after eliminating financial firms (that are Banks, Modaraba companies, Insurance companies etc). Out of 90 sample firms, 58 are classified as group affiliated firms whereas 32 are classified as non-group affiliated firms. The sample firms are distributed across 12 different sectors.

In order to see the effect of ownership structure of a firm on investment cash flow sensitivity we gather data for ownership structure from both business group affiliated firms and non-group affiliated firms. To achieve this purpose, we divided ownership structure into three different categories (I) Corporate ownership (2) Financial institution ownership and (3) Directors and family members ownership.

\section{Results and Discussion}

\subsection{Descriptive study}

We have shown the descriptive analysis of different variables in Table 1. As we wanted to create the investment-cash flow relationship of Pakistani business group and nonbusiness group affiliated firms, we have divided the entire sample according to group affiliation. We have shown the mean, median and standard deviation values of both business group and non-business group affiliated firms in Panel A. Mean values of business group affiliated firms and non-group affiliated firms based on size has been shown in Panel B.

The main aim of the study is the comparison of investment-cash flow sensitivity of group affiliated and non-group firms of Pakistan. The selected sample firms have been divided in to two 2 groups named as Panel A \& B. Panel A elaborates the mean, median and standard deviation of group affiliated and non-group affiliated firms. Panel B shows the mean values of both groups affiliated and non-group affiliated firms based on size categorization. These values differentiate between large and small firms. Our descriptive statistics findings are different for each sector due to different level of investment by these sectors in Pakistan. 
Table 1 (Panel A)

Summary

Statistics

Panel A: Business Group and Non-Group firms

\begin{tabular}{lccccccc}
\multicolumn{9}{c}{ Business Group } & & & \multicolumn{3}{c}{ Non- Group } \\
I/K & Mean & Median & Std. Dev. & Mean & Median & Std. Dev. & Mean \\
CF/ & 0.322 & 0.09 & 1.51 & 0.322 & 0.09 & 1.51 & 0.322 \\
K & 0.593 & 0.178 & 1.19 & 0.593 & 0.178 & 1.19 & 0.593 \\
Q & 827.854 & 581.432 & 912.062 & 827.854 & 581.432 & 912.062 & 827.854 \\
TA & 13669208 & 7936815 & 16228408 & 13669208 & 7936815 & 1622840 & 13669208 \\
TS & 14376974 & 7061056 & 24778289 & 14376974 & 7061056 & 2477828 & 14376974 \\
TS/K & 7.217 & 2.357 & 21.1 & 7.217 & 2.357 & 21.1 & 7.217 \\
D/K & 1.284 & 0.309 & 14.796 & 1.284 & 0.309 & 14.796 & 1.284 \\
AGE & 34.71 & 29 & 17.84 & 34.71 & 29 & 17.84 & 34.71 \\
COR & 46.63 & 52.09 & 28.99 & 46.63 & 52.09 & 28.99 & 46.63 \\
FIN & 15.2 & 13.11 & 11.72 & 15.2 & 13.11 & 11.72 & 15.2 \\
INS & 9.99 & 2.02 & 16.88 & 9.99 & 2.02 & 16.88 & 9.99
\end{tabular}

The descriptive statistics shown in Panel A indicate that there exists significant difference between means of investment to capital ratio $(\mathrm{I} / \mathrm{K})$ and cash flow to capital ratio $(\mathrm{CF} / \mathrm{K})$ of group affiliated and non-group firms. The mean, median and standard deviation of business group affiliated firms is higher than those of non-group affiliated firms. Higher values of both $(\mathrm{I} / \mathrm{K})$ and $(\mathrm{CF} / \mathrm{K})$ of group affiliated firms shows that group affiliated firms invested more in healthy projects and in return their profit margin is also high, on the other hand the investment of non-group affiliated firms is low due to which they are less profitable as compared to group affiliated firms.

The values of $\mathrm{Q}$ ratio for business group affiliated firms are smaller than those of nongroup affiliated firms except median values. The result shows that in business group affiliated firms the cost to replace a firm's assets is greater than the value of its stock. This indicates that the stock of group affiliated firms is undervalued. Conversely, a high $\mathrm{Q}$ values for non-group affiliated firms shows that a firm's stock is more expensive than the replacement cost of its assets, which indicates that the stock is overvalued. This measure of stock valuation is the driving factor behind investment decisions in Tobin's model.

Focusing on the size of firms, the size of the firms is measured based on total assets and total sale volume. The results indicate that mean, median and standard deviation values of total assets (TA) and total sales (TS) of group affiliated firms is lesser than the mean, median and standard deviation values of non-group affiliated firms. This means that nongroup affiliated firms are bigger than group affiliated firms. The level of leverage of a firm depends on many factors such as strength of operating cash flow, availability of 
deposit, and tax treatments. Thus, investors should be careful about comparing financial leverage between companies from different industries. The median and standard deviation values of leverage $(\mathrm{D} / \mathrm{K})$ for non-group affiliated firms is significantly greater than business group affiliated firms, whereas the mean values of leverage $(D / K)$ for business group affiliated firms is slightly higher than that of non-group affiliated firms. In Pakistan non-group affiliated firms are normally older than those of business group affiliated firms; the reason is that mostly non-group affiliated firms are under the Government control which starts operating soon after the independence in 1947. The mean age of non-group affiliated firms is 44.4 years compared 34.7 of group affiliated firms

Finally, we have found that there is significant difference in the ownership structure of Pakistani business group affiliated and non-group affiliated firms. The results of our finding show that COR (the mean percentage of shares held by other companies) of business group affiliated firms is larger than that of non-group affiliated firms. Which shows that within the same group the stakes held by domestic corporations can be considered as equivalent to insider holdings. These corporate owners play a significant role in the investment and financing decision-making of business group affiliated firms. The results of descriptive statistics also show that the mean percentage of shares FIN (\% of shares held by financial institutions) in business group affiliated firms and non-group affiliated firms is almost same, mean, median and standard deviation values of business group affiliated firms and non-group affiliated firms are slightly different. This means that the financial institution plays an important role in financing both groups affiliated and non-group affiliated firms in Pakistan. As most of the non-group affiliated firms are owned by the Government of Pakistan but financial institutions are privately owned in which government holds lesser influence and they are financing equally to both groups affiliated and non-group affiliated firms. The average INS (\% of shares held by directors and family members of the firm) ownership stake is higher in non-group affiliated firms and less for business group affiliated firms.

Panel A indicate that there exists significant difference between average values, median and standard deviation of each selected variables of group and non-grouped affiliated firms. Though the size and age of non-group affiliated firms are lesser as compared to non-group affiliated firms, but their investment, cash flow, margin of profit is higher. 
Table 1 (Panel B)

Panel B: Mean values of business group and non-group affiliated firms based on size categorization

\begin{tabular}{|c|c|c|c|}
\hline \multicolumn{2}{|c|}{ Business group firms } & \multicolumn{2}{|c|}{ Non-Group firms } \\
\hline Large & Small & Large & Small \\
\hline 0.529 & 0.113 & 0.089 & 0.143 \\
\hline 0.725 & 0.46 & 0.229 & 0.29 \\
\hline 838.039 & 817.597 & 598.265 & 1418.021 \\
\hline 24041948 & 3223421 & 82292207 & 2000205 \\
\hline 8.656 & 5.768 & 8.117 & 3.266 \\
\hline 2.275 & 0.285 & 0.505 & 0.424 \\
\hline 38.24 & 31.16 & 43.57 & 45.28 \\
\hline 47.16 & 46.1 & 33.8 & 35.05 \\
\hline 15.77 & 14.63 & 12.14 & 10.59 \\
\hline 9.45 & 10.53 & 13.11 & 28.85 \\
\hline
\end{tabular}

Panel B shows the categorization and classification of business group affiliated and nongroup affiliated firms' size, determined based on mean values of the firms as well as total assets. We further classified the sample firms into large and small sub-categories in order to see the difference in firm size within the category of both business group affiliated and non-group affiliated firms. The size subsamples classifications are based on the median values of the total assets of each category of firms. We considered those firms as large whom total assets value is greater than or equal to the median value of the sample. Whereas the firms whom value of total assets are smaller than the median of total sample is considered as small firm. The findings shown in Panel B of Table 1imply that for most of the variables, the mean values of large firms are higher from those of small firms. Within the same group, large and small variable has very small difference in most of the variables. On the other hand though large firms of business group affiliated firms has higher values as compared to large firms of non-group affiliated firms, but still there are some variables whom mean values under large category for both business group affiliated and non-group affiliated firms are almost same, same is the case under small category firms for both business group affiliated and non-group affiliated firms. The $(I / K)$ and $(C F / K)$ values of large size in group affiliated is higher than the $(I / K)$ and $(\mathrm{CF} / \mathrm{K})$ values of large size firms of non-group affiliated firms, whereas the $(\mathrm{I} / \mathrm{K})$ and (Q) values of small firms of non-group affiliated firms are higher than the same variables of group affiliated firms which shows that small firms of non-group affiliated firms performance is better than the small firms of group affiliated firms. 
4.2 Regression analysis

Regression results for the Q model.

Table 1: OLS estimation

Model (1) Model (2)

\begin{tabular}{|c|c|c|}
\hline Intercept & $-2.195^{*}(-4.39)$ & $-1.339^{*}(-3.12)$ \\
\hline $\mathbf{Q}$ & $0.0002^{*}(5.18)$ & $3.140(0.83)$ \\
\hline Cash Flow & $0.382^{*}(7.02)$ & $1.635^{*}(17.10)$ \\
\hline \multicolumn{3}{|c|}{ Cash Flow* } \\
\hline \multicolumn{2}{|c|}{ Group dummy } & $-1.610^{*}(-15.10)$ \\
\hline \multicolumn{2}{|c|}{ Group dummy } & $0.544^{*}(6.141)$ \\
\hline Size & $0.139 *(5.4)$ & $0.053^{*}(2.5)$ \\
\hline Age & $-0.041(-0.47)$ & $0.042(0.58)$ \\
\hline \multicolumn{3}{|l|}{ Time } \\
\hline \multicolumn{3}{|l|}{ \& Industry } \\
\hline dummies & Yes & Yes \\
\hline & & \\
\hline
\end{tabular}

Table 2: 2SLS estimation Model (3) Model (4)

$\begin{array}{cc}-2.528^{*}(-2.19) & -0.092^{*}(-0.08) \\ 0.0002^{*}(4.54) & 4.770(1.14) \\ 0.377^{*}(6.67) & 1.657^{*}(17.50) \\ & \\ & -1.598^{*}(-15.20) \\ & 0.432^{*}(3.370) \\ 0.138^{*}(5.291) & 0.054^{*}(2.45) \\ 0.059(0.18) & -0.304(-1.01) \\ & \\ & \\ \text { Yes } & \text { Yes } \\ 0.28 & 0.52\end{array}$

Table 1 show the regression results where OLS is used as the estimation method while table 2 presents the regression results where $2 S L S$ is used as estimation method. Investment to capital ratio is used as dependent variable in both the tables. $Q$ is the ratio of (Book value of total debt of firm + Market value of equity of a firm)/Book value of total assets of firm). Cash flow is for cash flow to capital ratio of a firm. The value of group dummy variable is 1 if the firm belongs to any business group and is 0 if it belongs to non-group affiliated firm. For size and age, natural log of total assets and number of years since incorporation has been used respectively. The heteroskedasticity and autocorrelation corrected absolute " $t$ " values are stated in parentheses. The total number of firm year observations is 450. Significance level at 1\%, 5\% and $10 \%$ levels are represented by *,** and $* * *$, respectively.

The relationship between cash flow and investment of a firm for business group and nonbusiness group affiliated firms is anticipated by using several alternative model specifications. Several specifications of the Q model in Eq. (2) for regression results have been shown in Table 2. Time and industry dummies are used to present the results. We include these dummies in order to control certain time varying macroeconomic factors. To check whether the phenomenon of business group affiliation affects the investment cash flow relationship of a firm we used interacting cash flow variable with group affiliation dummy variable.

First looking at the results presented in Table 1, the results indicate that there is a positive and statistically significant relationship between investment and Q in model (1) and there is a positive relationship between investment and Q in model (2). The results of the models of table 1 show different level of the estimated coefficient. The explanatory power of regressions is varying from $29 \%$ to $54 \%$ and is consistent with previous studies. Obtaining the results for cash flow variable, we observe that the estimated coefficient is positive and statistically significant in both model specifications of Panel 1. It indicates that cash flows are strongly related to investments for all firms. We also observe that the estimated cash flow coefficient in model (2) is greater than the 
estimated cash flow coefficient in model (1). The interaction coefficients of cash flow and group dummy variable in models $(2)$ is negative $(-1.61)$ but statistically significant. This finding is contrary to R. George et al. (2011) who found a positive relationship between investment to capital ratio and interaction coefficients of cash flow with group dummy variable.

In order to ensure that our findings are free from any biasness we used 2SLS technique. The same specifications have been estimated using 2SLS technique. The results eliminated using 2SLS specification is presented in table 2. The result shows that the coefficient of $\mathrm{Q}$ is found to be positive and statistically significant for model (3) and is positive for model (4) while the coefficient of cash flow is positive and statistically significant in both the models of table 2. Our findings are opposite to what many researchers expect for less financially constrained firms. Hoshi et al. (1991) while examining the Japanese has found that the investment cash flow sensitivity for group firms is less. Like Table 1, in Table 2 we have found that the coefficient of cash flow interacting with business group dummy in model (4) is negative but statistically significant. We have noticed that our results of less constrained business group affiliated firms, who are not revealing lower investment cash flow sensitivity, is not only the characteristic of Pakistani business groups alone, while studying the investment cash flow sensitivity between constrained and unconstrained firms of US economy, Allayannis and Mozumdar (2004) also do not observe any significant difference.

Both OLS and 2SLS results demonstrate that Q has insignificant coefficient in model (2) and (4) whereas Cash Flow has higher strong significant coefficient which clearly expresses that as a proxy for internal fund, Cash Flow explains more of the variation in investment than does Q, which certainly supporting the Fazzari, Hubbard \& Peterson (1988) argument. Generally, the variable Q is the ratio of the market value of total assets to book value of total assets of a business firm. As capital markets in Pakistan are relatively underdeveloped, group affiliated, and non-group affiliated firms always suffer from un-even market competition. Hence it could be better to consider sales as their investment opportunity instead of $\mathrm{Q}$ which is the general trend of the firm level recent empirical research on investment cash flow sensitivity.

The regressions analysis we presented in Table 2 is based on the full sample comprising of all firm year observations. Although for the time period of our study we considered large economic growth, but similarly at the same time there are certain economic crises which also influence our research like the financial crisis of 2007-2008, also known as the global financial crisis. In 2008, after the General Elections, uncertain political environment, rising militancy along western borders of the country, and mounting inflation and current account deficits resulted in the steep decline of the Karachi Stock Exchange. As a result, the corporate sector of Pakistan has declined dramatically in recent times.

Major reasons for the slow performance of the various sectors in Pakistan are global economic crisis, energy crisis, declining security situation in Pakistan, the flood situation and political instability which are still a big challenge for the government and are not under control yet. 
Table 3: Regression results for examining overinvestment of both groups affiliated and non-group affiliated firms

\begin{tabular}{|c|c|c|c|c|}
\hline & \multicolumn{2}{|c|}{ OLS } & \multicolumn{2}{|c|}{ 2SLS } \\
\hline Intercept & $\begin{array}{c}\text { Group } \\
-4.109^{*}(-5.78)\end{array}$ & $\begin{array}{l}\text { Non-Group } \\
-0.155(-1.04)\end{array}$ & $\begin{array}{c}\text { Group } \\
-5.047^{*}(-2.70)\end{array}$ & $\begin{array}{l}\text { Non-Group } \\
-0.149(-0.27)\end{array}$ \\
\hline $\mathbf{Q}$ & $0.007 *(9.03)$ & $-1.100(-1.07)$ & $0.007^{*}(8.91)$ & $-1.060(-0.81)$ \\
\hline Cash Flow & $0.517^{* *}(1.82)$ & $-0.050(-1.06)$ & $0.405(1.154)$ & $-0.049(-0.82)$ \\
\hline \multicolumn{5}{|l|}{ Cash FHow } \\
\hline *High Q & $-0.367(-1.29)$ & $0.049(0.84)$ & $-0.278(-0.86)$ & $0.040(0.63)$ \\
\hline Size & $0.225^{*}(6.17)$ & $-0.008(-1.18)$ & $0.222^{*}(5.10)$ & $-0.009(-0.27)$ \\
\hline Age & $0.030(0.24)$ & $0.113^{*}(4.10)$ & $0.324(0.62)$ & $0.117^{*}(4.13)$ \\
\hline \multicolumn{5}{|l|}{ Time and } \\
\hline \multicolumn{5}{|l|}{ Industry } \\
\hline Dummies & Yes & Yes & Yes & Yes \\
\hline $\mathbf{R}^{2}$ & 0.45 & 0.11 & 0.44 & 0.11 \\
\hline $\operatorname{Adj.} \mathbf{R}^{2}$ & 0.44 & 0.08 & 0.43 & 0.08 \\
\hline No. of Obs. & 285 & 165 & & \\
\hline
\end{tabular}

Table 3 shows the regression results where OLS and 2SLS are used as estimation method. Investment to capital ratio is used as dependent variable in both the tables. $Q$ is the ratio of (Book value of total debt of firm+ Market value of equity of a firm)/Book value of total assets of firm). Cash flow is for cash flow to capital ratio of a firm. High $Q$ is an indicator variable that is equal to one if business group affiliated or non-group affiliated firm's $Q$ is greater than or equal to the corresponding medians, and zero otherwise. For size and age, natural log of total assets and number of years since incorporation has been used respectively. The total number of firm year observations is 450. Significance level at 1\%, 5\% and 10\% levels are represented by*, ** and***, respectively.

We performed further sensitivity analysis of our results. The $\mathrm{Q}$ theory on investment implies that Higher the Q, the level of investment should be high, as stock values more highly present value of new capacity. Hoshi et al (1991) has demonstrated in his research work that the strong investment cash flow sensitivity of business group affiliated firms can be accredited to over investment made by the business group affiliated firms that has poor growth prospects. To study this phenomenon, we follow previous studies by using $\mathrm{Q}$ as a proxy for a firm's growth prospects. We divided our sample into High Q and Low $\mathrm{Q}$ firms based on the median values of these firms. Over investment by the business group affiliated firms can be the reason for higher sensitivity. Firms with meagre growth prospects (Low Q) should be more sensitive to their investment than the cash flows of firms with high growth prospects (High Q). Alti (2003) presents a model where the link between investment and cash flow is stronger for high growth firms because managers adjust current investment in response to cash flow realizations, which reflect current growth opportunities. The results of the analysis are presented in Table 3 . The results show that the cash flow interacting with High Q for group affiliated firms is negative and for non-group affiliated firm it is positively related to investment. It is believed that the business group affiliated firms have more access to the financial resources as compared to non-group affiliated firms, our findings indicated that the investment cash flow sensitivity is not a reliable source of measuring the financing constraints of the firm, thus contradiction the expectations. 
The influence of firm characteristics on investment cash flow sensitivity. In Table 1 of descriptive study, we have seen that the firm characteristics such as age, leverage, owner structure and size of business group affiliated firm is different than those of non-group affiliated. One can argue that whether investment cash flow sensitivity for business group affiliated firms and non-group affiliated firms are affected by these characteristics. Therefore, we perform additional analysis by dividing the total sample of business group affiliated and non-group affiliated sample into sub-sample in order to check whether these firm characteristics affects the investment cash flow sensitivity.

Size of firm

When the total assets of the firm are greater than their corresponding median value, we consider those firm as large and vice versa. The size of a firm may have effect on the investment cash flow sensitivity of the firm. Generally, it is believed that large size firms face less capital market imperfections as compared to small size firms, because in large size firms' lenders of funds must bear low screening and monitoring costs. Therefore, large size firms expected to reveal low investment cash flow sensitivity.

In large and business group affiliated firms, size has a significantly positive influence over investment made by them. It means when investments made by large size firms are larger as compared to small size firms. If the size of firm is large then the size of investment made by them is also large and vice versa confirming the findings of Palani et.al, (1998). The findings of Gertler and Gilchrist (1994) and Gilchrist and Himmelberg (1995) demonstrate that small firms are more sensitive to cash flow than larger firms. The theoretical argument to support these empirical results is that when the size of the firm is larger, they have easy access to external finance from financial institutions and banks.

Large firms are most likely to exploit economies of scale and enjoy higher negotiation power over their client and suppliers (Serrasqueire and MacasNunes 2008, Mansfield 1962, Singh and Whittington 1975) In addition they faces less difficulty in getting access to credit for investment, and many broad pools of qualified human capital and may achieve greatest strategic diversification (Yang and Chan 2009). To distinguish the investment cash flow sensitivity between business group-affiliated and non-group affiliated firms we add an interactive group dummy variable. 
Table 4

Regression analysis for the size sub-samples.

\begin{tabular}{|c|c|c|c|c|}
\hline & Large firms & Small Firms & Group affiliated & Non-Group \\
\hline Intercept & $-2.213^{*}(-2.37)$ & $-0.325(-1.46)$ & $-4.096^{*}(-5.13)$ & $-0.371^{* *}(-1.82)$ \\
\hline $\mathbf{Q}$ & $0.003^{*}(4.23)$ & $-1.280(-1.12)$ & $0.007^{*}(9.26)$ & $-1.400(-1.31)$ \\
\hline Cash Flow & $1.433^{*}(9.50)$ & $0.018(0.27)$ & $-0.302 *(-2.54)$ & $0.018(0.30)$ \\
\hline \multicolumn{5}{|l|}{ Cash Flow* } \\
\hline Group dummy & $-1.419 *(-9.42)$ & $0.020(0.27)$ & & \\
\hline Group dummy & $0.599^{*}(3.84)$ & $-0.032(-0.91)$ & & \\
\hline Cash Flow*Size dummy & & & $0.608^{*}(4.63)$ & $-0.055(-0.80)$ \\
\hline Size dummy & & & $-0.521 *(-3.06)$ & $-0.064(-1.17)$ \\
\hline Size & $0.090^{*}(1.90)$ & $0.017(1.21)$ & $0.530 *(14.70)$ & $0.007(0.59)$ \\
\hline Age & $0.043(0.36)$ & $0.060^{*}(2.12)$ & $0.087(0.72)$ & $0.111^{*}(4.07)$ \\
\hline Time \& Industry dummies & Yes & Yes & Yes & Yes \\
\hline $\mathbf{R}^{2}$ & 0.63 & 0.05 & 0.49 & 0.12 \\
\hline Adj.. $\mathbf{R}^{2}$ & 0.62 & 0.02 & 0.48 & 0.08 \\
\hline No. of Obs. & 225 & 225 & 285 & 165 \\
\hline
\end{tabular}

The table 4 presents the ordinary least squares regression results Investment to capital ratio is used as dependent variable in both the tables. $Q$ is the ratio of (Book value of total debt of firm+ Market value of equity of a firm)/Book value of total assets of firm). Cash flow is for cash flow to capital ratio of a firm. The value of group dummy variable is 1 if the firm belongs to any business group and is 0 if it belongs to non-group affiliated firm. Size dummy is variable that is equal to one if the size of business group or nongroup affiliated firm is larger than or equal to median values, and zero otherwise for size and age, natural log of total assets and number of years since incorporation has been used respectively. The total number of firm year observations is 450. Significance level at 1\%, 5\% and $10 \%$ levels are represented by *,**and***, respectively.

We performed additional analysis in order to measure the impact of various firm specific characteristics of both business group affiliated and non-group affiliated firms on investment cash flow sensitivity of firms.

Our first categorization is made based on size of the firm. The results of Table 4 show that in the sub sample of large firm the coefficient of cash flow with interacting group dummy is negatively significant while in sub sample of small firms it is positive. These findings are opposite to the findings of Azam and Shah (2011) that invested 52 listed firms in Karachi Stock Exchange and found a positive relationship between investment and size of the firm. We further examine our analysis by dividing our sample into business group affiliated and non-group affiliated firms. We used size dummy which is equal to 1 when the value of total assets of a business group affiliated group (non-group affiliated) firms are higher than the median, and zero otherwise. The results presented in the last two columns of Table 5 shows that the investment cash flow sensitivity from large non-group affiliated firm is negative, while it is positive and statistically significant for large business group-affiliated firms. 


\section{Age of firm}

It is generally considered that age of the firm plays a key role in the financing constraints of the firm. Generally, it is believed that younger firm's faces higher financial constraints and older firm faces fewer financial constraints, one of the main reasons is that older firms have better credit record, information asymmetric, and less default chances. On the other hands younger firms are less likely to obtained external finance, and investment made by them are more opaque and riskier. Similarly, these firms were unable to win investors' confidence. We examine whether the differences in age (number of years since incorporated) of the firm affects the investment cash flow sensitivity of business group affiliated and non-group affiliated firms. The findings of our research are presented in Table 6. We split the full sample into business group affiliated and non-group affiliated firms. In Table 6 , in addition to the earlier used explanatory variables, we used the interacting cash flow variable with a dummy variable which identifies older or younger firms. The result indicates that cash flow has a negative relationship with Investment for business group-affiliated firms and is positive for non-group affiliated firms; in both the cases the results are insignificant. But the interaction coefficients are negatively significant for group-affiliated firms only.

\section{Leverage of firm}

The amount of leverage can also affect the investment cash flow sensitivity of a firm. It is generally observed that those companies (either business group affiliated, or nongroup affiliated) having high leverage value, faces more difficulty in obtaining additional external funds from the capital market, and therefore they are expected to be more financially constrained than those having low leverage values.

In Table 6 we presented results for age and leverage characteristics of a firm for both business group affiliated firms and non-group affiliated firms. The result shows that for business group-affiliated firms, the investment cash flow sensitivity is negative for those firms which are highly leveraged and is positive to low leveraged firms. Similarly, the leverage interaction variable is negative and statistically significant for group-affiliated firms and is negative and insignificant for non-group firms. When a firm has high leverage then it is difficult for them to obtain additional fund and thus high investment cash flow sensitivity is expected. 
Table 5: Regression analysis for the age and the leverage sub-samples.

\begin{tabular}{|c|c|c|c|c|}
\hline & \multicolumn{2}{|c|}{ Age of firm } & \multicolumn{2}{|c|}{ Leverage of firm } \\
\hline & \multirow{3}{*}{$\begin{array}{l}\text { Group affiliated } \\
-4.010^{*}(-4.39) \\
0.008^{*}(9.62)\end{array}$} & \multirow{2}{*}{$\begin{array}{l}\text { Non-Group } \\
-0.244(-1.21)\end{array}$} & \multirow{2}{*}{$\begin{array}{c}\text { Group affiliated } \\
-2.157^{*}(-2.99)\end{array}$} & \multirow{2}{*}{$\begin{array}{r}\text { Non-Group } \\
-0.115(-0.71)\end{array}$} \\
\hline Intercept & & & & \\
\hline $\mathbf{Q}$ & & $-7.100(-0.70)$ & \multicolumn{2}{|c|}{$0.006 *(7.850)$} \\
\hline Cash Flow & $-0.536^{*}(-2.74)$ & $0.005(0.08)$ & $-0.154^{*}(-1.84)$ & $0.031(0.52)$ \\
\hline Cash Flow*Age dummy & $0.762^{*}(3.83)$ & $-0.032(-0.44)$ & & \\
\hline Age dummy & $-0.407(-1.51)$ & $-0.023(-0.44)$ & & \\
\hline \multicolumn{3}{|l|}{ Cash Flow*Leverage dummy } & $-0.127(-0.82)$ & $-0.060(-0.90)$ \\
\hline \multicolumn{3}{|l|}{ Leverage dummy } & $0.109^{*}(2.67)$ & $0.047(1.18)$ \\
\hline Size & $0.207^{*}(5.73)$ & $-0.008(-1.10)$ & $0.391^{*}(10.70)$ & $-0.013(-1.51)$ \\
\hline Age & $0.165(0.70)$ & $0.139 *(2.89)$ & $0.063(0.56)$ & $0.119^{*}(4.28)$ \\
\hline Time \& Industry dummies & Yes & Yes & Yes & Yes \\
\hline $\mathbf{R}^{2}$ & 0.47 & 0.10 & 0.58 & 0.11 \\
\hline Adj. $\mathbf{R}^{2}$ & 0.46 & 0.07 & 0.57 & 0.08 \\
\hline No. of Obs. & 285 & 165 & 285 & 165 \\
\hline
\end{tabular}

The table 5 presents the ordinary least squares regression results Investment to capital ratio is used as dependent variable in both the tables. $Q$ is the ratio of (Book value of total debt of firm+ Market value of equity of a firm)/Book value of total assets of firm). Cash flow is for cash flow to capital ratio of a firm. The Age dummy and leverage dummy are equal to one if the resultant values are greater than or equal to the business group and non-group affiliated medians, and zero otherwise. For size and age, natural log of total assets and number of years since incorporation has been used respectively. The total number of firm year observations is 450. Significance level at 1\%, 5\% and $10 \%$ levels are represented by *,**and***, respectively.

The interacting cash flow with Age dummy shows significant positive impact on investment cash flow for business group affiliated firms; the result shows that older firms have an established reputation in the market, which facilitates their access to external finance, mainly because their relationships with creditors settled within a longer time span. The results are going in the favour of Kashanipoor et al (2010) who found a positive relationship between investment-cash flow sensitivity and age. However, it has insignificant impact on non-group affiliated firms the result implies that the investment in fixed assets is made by the company when they are younger but with the passage of time, as company tends to grow older, they decrease the investment in fixed assets decreases when the company grows older. Our finding goes in the favour of Azam and Anum (2011) and Lin et al (1999) who found negative relationship between investment and age of firm.

Those companies who have high leverage are considered more financially constrained because they face difficulties in obtaining additional external funds from the capital market and vice versa. In case of non-group affiliated firm high investment, cash flow sensitivity is expected. The results presented in Table 6 shows that in case of business group-affiliated firms, there is no difference in the investment cash flow sensitivity of love leveraged and high leveraged firms, similarly the cash flow interacting dummy with leverage is negative for both business group affiliated and non-group affiliated firms. 


\section{Ownership structure of firm}

In Pakistani capital market almost $60 \%$ of the firms have affiliation with large business groups and are owned by the family members, due to which major portion of shares are either held by family members or by the managers of the firms. Ashraf.J. and Ghani (2004) and Attiya. Y. Javed (2012) have describe that the Pakistani firms have a pyramid and cross holding ownership structure which tends to agency conflict and the outsiders especially in case of business groups it is difficult to understand the ownership structure. Organizations authoritative hierarchy has its effect on the sensitivity of investment and cash flow by the quality of command and control of the shareholder. What policies the head implements and what resources he brings in for business expansion. The efficiency of the shareholders' command and control is expected to reduce the risk of mismanagement and irregularity of data. As it's properly controlled from the top so the expected problems at the lower end can be reduced to a great extent. Due to which the sensitivity of investment and cash flow can be reduce to a great extent so as financial hindrance creating factors. Different shareholders implement different monitoring style so its impact should be studied separately.

Authority is distributed according to the shares the shareholders have within the organization to the outstanding shares in total(Rozeff 1982;Al-Malkawi,2007) If the firm is strong from inside then it will automatically become strong from outside and this can only be done by excellent command and control that why authority holder play vital role in firms progress and aligning the management and shareholders interest towards firm's goal and ultimately decreasing the requirement to pay high dividends. Hence negative relationship between inside authority and dividend policy is figured out. (Jensen and Meckling 1976, Rozeff 1982, Jensen et al 1992)

Table 6: Regression results for the ownership structure sub-samples of firms

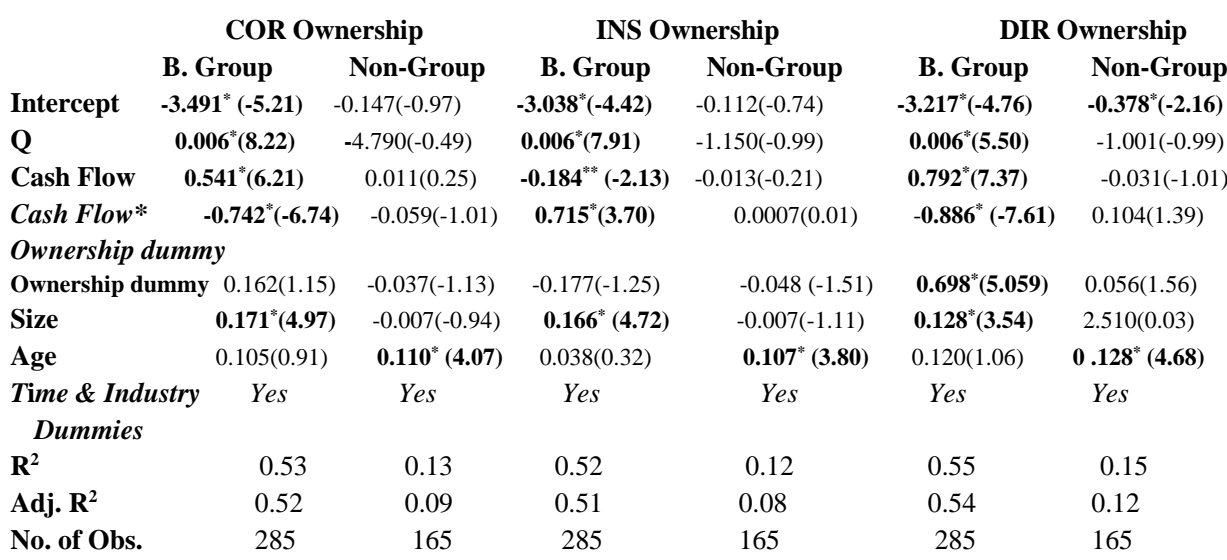


The table 7 presents the ordinary least squares regression results Investment to capital ratio is used as dependent variable in both the tables. $Q$ is the ratio of (Book value of total debt of firm+ Market value of equity of a firm)/Book value of total assets of firm). Cash flow is for cash flow to capital ratio of a firm. Ownership dummy is equal to one if the resultant ownership values are greater than or equal to the group or non-group sample median, and zero otherwise. For size and age, natural log of total assets and number of years since incorporation has been used respectively. The total number of firm year observations is 450. Significance level at 1\%, 5\% and 10\% levels are represented by *, ** and ${ }^{* * *}$, respectively.

Finally, we analyse the investment cash flow sensitivity with respect to firm's ownership structure. It is commonly observed that when large shareholders have active monitoring on investment decision of the firm, it will reduce the managerial discretion and information asymmetry, resulting in reducing the firms financing constraints. We observe that corporate ownership has a negative impact on business group affiliated and non-group firms. These findings are opposite to the findings of Regie. Et al (2011) who while examining business group and non-group affiliated firms of India has found that corporate ownership did not affect the investment-cash flow sensitivity of business group affiliated firms and has positive effect on non-group affiliated firms. Institutional Ownership has significant positive relationship impact on group affiliated firm and positive relationship impact on non-group affiliated firms. While the insider ownership has significant negative relationship impact on group affiliated firm and positive impact on non-group affiliated firms. These results are in favour that firms having higher level of insider shareholders expecting lower investment-cash flow sensitivity.

\section{Conclusion}

Financial constraints have been one of the serious affairs in the business world. This issue comes up when a company must go for financing being opted for either internal financing or external financing. Often internal financing is preferred over external financing. The pioneers of the researchers who studied and used the investment and cash flow as the sensitivity measurement indicator of the firm's financial hindrances says that it's not always the investment and cash flow increase together equally sometimes it collapses in the case of cost which firm can handle and the cost of production and its function. The purpose of the research is to find out the touchy financial factors which create the different in investment and cash flow highlighting the Pakistani affiliated and non-affiliated business groups. Previous research suggested that since business group affiliated firms helps in reducing their financial constraints, these firms should face lower investment-cash flow sensitivity. On the other hand, non-group affiliated firms are more at risk and face more changing threats that's why study is more emphasized on affiliated business and non-business groups of Pakistan.

For investment and cash flow sensitivity of Pakistani business group-affiliated firms we have found statistically significant and positive results but for non-group affiliated firms the results are negative which contradicts with the findings of previous researches in which positive results were found even in non-affiliated groups. Our findings show a positive relationship between $\mathrm{Q}$, cash flow and investment of a firm for business group- 
affiliated firms under both OLS and 2SLS estimation while we have found a negative relationship between $\mathrm{Q}$, cash flow and investment for non-group affiliated firms. These results show that business group affiliated firms in Pakistan are less financially constrained as compared to non-group affiliated firms.

We have also found that for both group- affiliated and non-group firms' value of Q and cash flow shows positive and statistically significance results with respect to relationship with investment, on the other hand interacting group dummy shows negative relationship with investment. Group dummy shows positive relationship with investment. It was further pointed out that for group affiliated firms, relationship between $\mathrm{Q}$ and investment and investment and cash flow is positive and statistically significant even if the firm goes for over investment, while the same relationship is negative for non-group affiliated firm which is very supportive to the study's outcomes.

We have further examined several firm-specific characteristics such as age, size, leverage and ownership structure of the firm. Several robustness checks using alternative estimation stipulation and methodologies were used. The findings of our research show that age of the firm is significant and is positively related with investment for non-group affiliated firms while it is negative for business group affiliated firms the reason is that the non-group affiliated firms are mainly under the government control and they started their business earlier as compared to business group affiliated firms. On the other hand, group affiliated firms are having higher leverage as compared to non-group affiliated firms. The larger the size of the firm the positive is the relationship of the investment and it goes with more investment as compared to small groups and it shows negative relationship with the non-group affiliated firm. It is so because the hierarchy in group affiliated firm is taller than non-group affiliated firms.

Our final findings are ownership structure of the firms. We use three ownership structure of the firm in order to measure financial constraints of the firm. Number of shares held by the corporations, number of shares held by the financial institutions and the number of shares held by directors and family members of the firms. Our results show that corporate ownership is positively related to investment for business group affiliated firms and is negatively related to investment for non-group affiliated firms. Institutional ownership is negatively related to both business group affiliated and non-group affiliated firms, while the insider ownership is positively significant with investment for business group affiliated firms and is negatively related to investment for non-group affiliated firms.

The findings of our study have shown that in Pakistan business group- affiliated firms are less financially constraint as compared to non-group affiliated firms which implies that government of Pakistan should provide good governance and healthy investment scenario in a country that attract foreign investors. Most of the non-group affiliated firms are under the control of local government and their performance is poor in terms of investment and cash flow sensitivity. Government should have to modify their investment plans in order to meet the cash flow on time.

This research study includes only 12 sectors out of 32 Listed Business Sectors registered on KSE. This research study did not include any Financial Institutions (that are Banks, 
Modaraba companies, Insurance companies etc). Among various investment models we have used only Q model which is used to measure investment -cash flow sensitivity indicator with respect to financial constraints of the firm.

\section{References}

Aggarwal, R., Zong, S., 2006. The cash flow-investment relationship: international evidence of limited access to external finance. Journal of Multinational Financial Management 16, 89104.

Alexander Dyck \& Luigi Zingales, 2004. "Private Benefits of Control: An International Comparison," Journal of Finance, American Finance Association, vol. 59(2), pages 537$600,04$.

Allayannis G., Mozumdar A., 2004. The impact of negative cash flow and influential observations on investment-cash flow sensitivity estimates. Journal of Banking and Finance 28 (5), 901 930.

Almeida, H., M. Campello, and M. Weisbach, (2004). The Cash Flow Sensitivity of Cash. Journal of Finance, 59 (4), 1777-1804.

Alti A., 2003. How sensitive is investment to cash flow when financing is frictionless? Journal of Finance 58, 707-722.

Anderson, R.C. Mansi, S., \& Reeb, D. M. (2003). Founding family ownership and the agency cost of debt. Journal of Financial Economics, 68,263-285.

Bhaduri, S., 2005. Investment, financial constraints and financial liberalization: some stylized facts from a developing economy, India. Journal of Asian Economics 16, 704-718.

Bond, S., Harhoof, D. and Van Reeenen, J. (2007), "Investment, R\&D and Financial Constraints in Britain and Germany”, Annalesd'Economieet de Statistique (forthcoming).

Chang, S., Hong, J., 2000. Economic performance of group-affiliated companies in Korea: intra group resource sharing and internal business transactions. Academy of Management Journal 43, 429-448.

Cheema, A., 1999. Rent-Seeking, Institutional Change and Industrial Performance: The Effect of State Regulation on the Productivity Growth Performance of Pakistan's Spinning Sector, 1981-94. PhD Dissertation, Department of Economics, University of Cambridge, Cambridge.

Cheema, A., 2003. Corporate Governance in Pakistan: Issues and Concerns. NIPA Journal,8(2), 718.

Claessens, S., Djankov, S., Fan, J.P.H., Lang, L., 2003. The benefits and costs of internal markets: Evidence from East Asia's financial crisis. In: Fan, J.P.H., Hanazaki,

M., Teranishi, J. (Eds.), Designing Financial Systems in East Asia and Japan - Toward a TwentyFirst Century Paradigm. London: Routledge.

Claessens, S., Fan, J., and Lang, L. (2006). The benefits and costs of group affiliation: Evidence from East Asia. Emerging Markets Review 7, 1-26.

Cleary, S., 1999.The relationship between firm investment and financial status. Journal of Finance 54, 673-692.

Cleary, S., 2006.International corporate investment and the relationships between financial constraint measures. Journal of Banking and Finance 30, 1559-1580. 
Cleary, S., Povel, P., Raith, M., 2007. The U-shaped investment curve: theory and evidence. Journal of Financial and Quantitative Analysis 42, 1-40.

Cull, R., Demirgüç-Kunt, A., Morduch, J. (2007). "Financial performance and outreach: a global analysis of lead ing microbanks". Economic Journal 117, F107-F133.

David J. Denis, Valeriy Sibilkov, (2010), Financial Constraints, Investment, and the Value of Cash Holdings. The Review of Financial Studies, 23(11).

Degryse, H, De Jong, A., 2006. Investment and internal finance: asymmetric information or managerial discretion. International Journal of Industrial Organization 24, 125-147.

DeMarzo, Peter and Michael Fishman (2000): Optimal Long-Term Financial Contracting with Privately Observed Cash Flows. Mimeo, Stanford University and North-western University.

DeMarzo, Peter, and Michael Fishman, 2007, Optimal long-term financial contracting, Review of Financial Studies 20: 2079-2128.

Faccio, Mara and Larry H.P. Lang. 2002. "The Ultimate Ownership in Western European Corporations," Journal of Financial Economics 65:3, pp. 365-395.

Fazzari, S., Hubbard, R., Petersen, B., 2000. Investment-cash flow sensitivities are useful: a comment on Kaplan and Zingales. Quarterly Journal of Economics 115, 695-705.

Fazzari, S.M., Hubbard, R.G., Petersen, B.C., 1988. Financing constraints and corporate investment. Brookings Papers on Economic Activity 1, 141-195.

Fazzari, S., Hubbard, R., Petersen, B., 1988.Financing constraints and corporate investment. Brookings Papers on Economic Activity 1, 141-195.

Ghosh, S., 2006. Did financial liberalization ease financing constraints? Evidence from Indian firm-level data. Emerging Markets Review 7, 176-190.

Goergen, M., Renneboog, L., 2001.Investment policy, internal financing and ownership concentration in the UK. Journal of Corporate Finance 7, 257-284.

Gomes, Joao F., 2001, Financing investment, American Economic Review 90, 1263 -1285.

Granovetter, M. (1994), "Business groups", in Smelser, N. and Swedberg, R. (Eds), The Handbook of Economic Sociology, Princeton University Press, Princeton, NJ, pp. 453-75.

Granovetter, M.S. 2003. "Business Groups and Social Organization.” In N. Smelser and R. Swedberg (eds.), Handbook of Economic Sociology, $2^{\text {nd }}$ edition Guariglia, A., 2008 Internal financial constraints, external financial constraints and investment choice: Evidence from a panel of UK firms. Journal of Banking and Finance 32, 1795-1809.

Guillen, M., 2001. The Limits of Convergence: Globalization and Organizational Change in Argentina, South Korea and Spain. Princeton University Press, Princeton.

Hoshi, T., A. Kashyap, and D. Scharfstein. 1991. Corporate structure, liquidity and investment:Evidence from Japanese industrial groups. The Quarterly Journal of Economics 106 (1): 33-60.

Hovakimian, G., 2009. Determinants of investment cash flow sensitivity. Financial Management $38,161-183$

Hubbard, R., 1998. Capital-market imperfections and investment. Journal of Economic Literature 36, 193-225. 


\section{Vol. 5 Issue: 1/ April 2020}

Kaplan, S., Zingales, L., 1997. Do investment-cash flow sensitivities provide useful measures of financing constraints? Quarterly Journal of Economics 112, 169-216.

Kadapakkam, RR. P.C. Kumar and L. A. Riddick (1998), "The impact of cash flows and firm size on investment: the international evidence", Journal of Banking \& Finance,22, p. 293-320.

Kaplan, S., Zingales, L., 2000. Investment-cash flow sensitivities are not valid measures of financing constraints. Quarterly Journal of Economics 115, 707-712.

Keister, L. A. (1998). Engineering growth: Business group structure and firm performance in China's transition economy. American Journal of Sociology ,104, 404-440.

Khanna, T. and J. Rivkin. 2001. "Estimating the Performance Effects of Business Groups in Emerging Markets.” Strategic Management Journal (22), 45-74.

Khanna, Tarun, and Krishna Palepu, 2000. Is Group Affiliation Profitable in Emerging Markets? An Analysis of Diversified Indian Business Groups, Journal of Finance 55, 867-891.

Jensen, Michael C., and William H. Meckling. 1976. "The Theory of the Firm: Managerial Behavior, Agency Cost, and Ownership Structure." Journal of Financial Economics 3, no. 4 (October): 305-60.

Johnson, Simon, Rafael La Porta, Florencio Lopez-de-Silanes, and Andrei Shleifer, 2000, Tunneling, American Economic Review 90, 22-27.

Laeven, L., 2003. Does financial liberalization reduce financing constraints? Financial Management 32 (Spring), 5-34.

La Porta, R., Lopez-De-Silanes, F., \& Shleifer, A. 1999. Corporate ownership around the world. Journal of Finance, 54: 471-517.

La Porta, R., Lopez-de-Silanes, F., Shleifer, A., Vishny, R., 2000. Investor protection and corporate governance. Journal of Financial Economics 58, 3-27.

Leff, N. (1978), 'Industrial Organization and Entrepreneurship in the Developing Countries: The Economic Groups,' Economic Development and Cultural Change, 26 (July), 661-675.

Lensink, R., Van der Molen, R., Gangopadhyay, S., 2003. Business groups, financing constraints and investments: the case of India. Journal of Development Studies 40, 93-119.

Lensink, R., Bo, H., Sterken, E., 2001. Investment, Capital Market Imperfections and Uncertainty: Theory and Empirical Results. Edward Elgar, Cheltenham, UK.

Manos, R., Murinde, V., \& Green, C. J. (2007). Leverage and Business Groups: Evidence from Indian Firms, Journal of Economics \& Business, 59(5), pp. 443-46.

Maury, B., 2006. Family ownership and firm performance: empirical evidence from western European corporations. J. Corp. Finance 12, 321-341.

Mir, S.R. and M. Nishat, 2004. Corporate Governance Structure and Firm Performance in Pakistan- An Empirical Study. Paper presented in LUMS-SEC Conference on 'Corporate Governance in Pakistan: Regulation, Supervision, and Performance'. Lahore: Lahore University of Management Sciences, May 29-30.

Moyen, Nathalie, 2004, Investment-cash f low sensitivities: Constrained versus unconstrained firms, Journal of Finance 59, 2061-2092.

Mullainathan et al. 2000. Ferreting Out Tunnelling: An Application to Indian Business Groups. Quarterly Journal of Economics, 117(1), 121-148. 
Myers S.C. and N.S. Majluf, 1984. Corporate financing and investment decisions when firms have infor-mation that investors do not have, Journal of Financial Economics 13, $187-221$.

Naqvi, S.A.A. and A. Ikram, 2004. Group Affiliation, Firm Performance, and Corporate Governance in Pakistan: Evidence from the Textile Sector. Paper presented in LUMSSEC Conference on 'Corporate Governance in Pakistan: Regulation, Supervision, and Performance'. Lahore: Lahore University of Management Sciences, May 29-30.

Olley,G.S.,and A. Pakes. 1996. The dynamics of productivity in the telecommunications equipment industry. Econometrica64: 1263-1297.

Perotti, E., Gelfer, S. 2001. Red barons or robber barons? Governance and investment in Russian financial-industrial groups. European Economic Review 45, 1601-1617.

Sai Ding, Alessandra Guariglia and John Knight, (2010), Investment and financing constraints in china: does working capital management make a difference? RePEc: gla: glaewp:2010_33.

Scharfstein, D.S., Stein, J.C., 2000. The dark side of internal capital markets: Divisional rentseeking and inefficient investment. Journal of Finance 55, 2537-2564.

Shen, C.-H., Wang, C.-A., 2005. Does bank relationship matter for a firm's investment and financial constraints? The case of Taiwan. Pacific-Basin Finance Journal 13, 163-184.

Shleifer, A., \& Vishny, R. W. (1997). A survey of corporate governance. Journal of Finance, 52, $759-783$.

Singh, D. A., \& Gaur, A. S. (2009). Business group affiliation, firm governance and firm performance: evidence from China and India. Corporate Governance, 17(4), 411-425.

Sraer, D., Thesmar, D., 2007. Performance and behavior of family firms: evidence from the French stock market. J. Eur. Econ. Assoc. 5, 709-751.

Teranishi, J. (Eds.), Designing Financial Systems in East Asia and Japan - Toward Twenty-First Century Paradigm. London: Routledge.

Thompson, E. P. (1971), The Moral Economy of the English Crowd in the Eighteenth Century, Past and Present, 50 (February), 76-136.

Toni M. Whited, (2006), External finance constraints and the inter-temporal pattern of intermittent investment. Journal of Financial Economics, 81.

Tarziján, J. (1999). Internal Capital Markets and Multimarket contact as explanations for conglomerates in emerging markets. ABANTE, Vol 2, No.1.

Wang, D. (2006). Founding family ownership and earnings quality. Journal of Accounting Research, vol. 44, no. 3, 619-656.

White, L., 1974. Industrial Concentration and Economic Power in Pakistan. Princeton, NJ: Princeton University Press.

Williamson, Oliver (1975), Markets and Hierarchies, The Free Press, New York.

Villalonga, B., \& Amit, R. (2006). How do family ownership, control, and management affect firm value? Journal of Financial Economics,80, 385-417.

Zhangkai Huang, St. Hugh's College (2002), Financial Constraints and Investment-Cash Flow sensitivity. Social Science Research Network. 
